\title{
Pelatihan Pembuatan Pupuk Organik Cair Eceng Gondok dan Keong Mas di Dusun Semen Kabupaten Semarang
}

\author{
Muhimmatul Ifadah ${ }^{1}$, Rafaella Chandraseta Megananda ${ }^{2}$, Nabilatus Sunayya ${ }^{3}$ \\ Afni Harfina ${ }^{4}$, Florentina Kusmiyati ${ }^{5}$ \\ 1,2,3,4,5 Universitas Diponegoro \\ email : muhimatulifada63@gmail.com¹, rchandraseta@gmail.com², nabilatussunayya@gmail.com ${ }^{3}$, \\ afniharfina123@gmail.com ${ }^{4}$, fkusmiyati@lecturer.undip.ac.id ${ }^{5}$
}

\begin{abstract}
The activities aim to improve the skills, understanding, and knowledge of PKK in Semen village in processing water hyacinth and golden snails into liquid organic fertilizer. Activities are carried out using two methods, namely online and offline. Activities carried out offline include observations and preparations carried out by direct interviews with village officials and making modules and video tutorials. The training was conducted offline using a demo method of making liquid organic fertilizer. The mentoring method is carried out online through the Whatsapp group regarding the development of fertilizer fermentation that has been made. Evaluation of the activities carried out online includes filling out a questionnaire using a google form to find out the understanding of PKK after the activity. Based on the filling in the questionnaire, it shows that PKK already understands how to process water hyacinth and golden snails into liquid organic fertilizer. After the training activities have been carried out, this liquid organic fertilizer can be used by $P K K$, it is hoped that after the program there is a change in the behavior pattern of PKK in using inorganic fertilizers to their organic fertilizers.
\end{abstract}

Keywords: training, golden snail, water hyacinth, liquid organic fertilizer.

\begin{abstract}
Abstrak
Kegiatan ini bertujuan untuk meningkatkan keterampilan, pemahaman, serta pengetahuan Ibu-Ibu PKK dusun Semen dalam mengolah eceng gondok dan keong mas menjadi pupuk organik cair. Kegiatan dilakukan dengan dua metode yakni daring dan luring. Kegiatan yang dilaksakan secara luring meliputi observasi dan persiapan dilakukan dengan wawancara secara langsung dengan petinggi desa dan pembuatan modul serta video tutorial. Pelatihan dilakukan secara luring dengan metode demo pembuatan pupuk organik cair. Metode pendampingan dilakukan secara daring melalui grup whatsapp mengenai perkembangan fermentasi pupuk yang telah dibuat. Evaluasi kegiatan dilakukan secara daring meliputi pengisian angket menggunakan google form untuk mengetahui pemahaman Ibu-Ibu PKK pasca kegiatan. Berdasarkan pengisian kuisioner menunjukkan bahwa Ibu PKK sudah memahami cara mengolah eceng gondok dan keong mas menjadi pupuk organik cair. Setelah kegiatan pelatihan dilaksanakan, pupuk organik cair ini dapat digunakan oleh Ibu PKK harapan setelah program adalah terdapat perubahan pola perilaku Ibu PKK dalam menggunakan pupuk tanaman yang berlaih dengan pupuk buatannya sendiri.
\end{abstract}

Kata Kunci: pelatihan, keong mas, eceng gondok, pupuk organik cair.

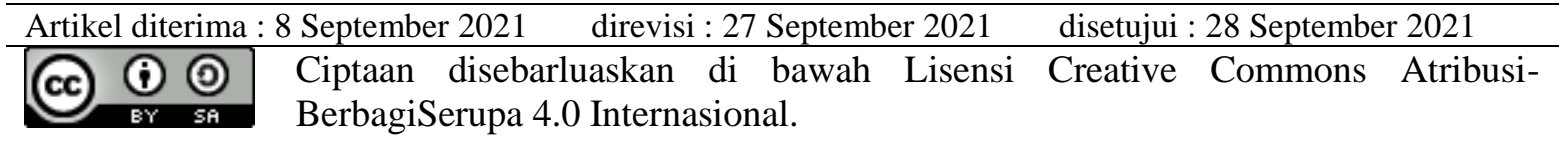




\section{Pendahuluan}

Tingkat keberdayaan perempuan di berbagai bidang merupakan salah satu tanda meningkatnya kesejahteraan (Utomo $\&$ Prihatin, 2020). Kesejahteraan rumah tangga dapat dikatakan mengalami peningkatan ketika perempuan memiliki hak kepemilikan yang setara, terdidik, serta mempunyai kebebasan dalam segala bidang termasuk bekerja di luar rumah sendiri dan memiliki pendapatan. Perempuan memiliki peran signifikan dalam menurunkan angka kemiskinan dengan cara pemberdayaan di dalam masyarakat. Bentuk nyata kontribusi perempuan dapat meningkatkan kesejahteraan keluarga dapat dilihat pada sektor UMKM sebanyak 65\% UMKM dimiliki oleh perempuan (Zurani, 2020).

Dusun Semen desa Tlompakan terletak di kecamatan Tuntang, kabupaten Semarang provinsi Jawa Tengah. Dusun Semen memiliki total luas $317.285 \mathrm{~m}^{2}$ dengan rincian $83.600 \mathrm{~m}^{2}$ merupakan area pemukiman sedangkan sisanya merupakan area pertanian sawah dan lahan kering serta hutan. Masyarakat Semen umumnya bekerja sebagai petani yang didominasi oleh laki-laki. Dusun Semen memiliki beberapa kelompok ibu-ibu yang tergabung dalam PKK (Pembinaan Kesejahteraan Keluarga) dengan latar belakang pendidikan umumnya lulusan SLTP dimana hampir keseluruhan ibu-ibu PKK merupakan ibu rumah tangga dengan ekonomi menengah ke bawah. Beberapa anggota PKK dusun Semen memiliki usaha sampingan berjualan makanan ringan. Di sisi lain, kegiatan berjualan yang dilakukan oleh beberapa ibu-ibu PKK terhambat karena pandemi covid-19 dan ibu-ibu PKK tidak memiliki ketrampilan lain untuk dikembangkan sebagai usaha sampingan.

Ibu-ibu PKK dusun Semen merupakan kelompok aktif dalam melakukan kegiatan dan tergolong sebagai tenaga kerja produktif yang memiliki potensi untuk diberdayakan melalui program pengabdian. Kegiatan pemberdayaan yang dilakukan memiliki beerapa tujuan diantaranya adalah 1) meningkatkan ketrampilan Ibuibu PKK, 2) menumbuhkan kemandirian sektor UMKM dan memperluas lapangan kerja, 3) menumbuhkan semangat jiwa wirausaha. Tujuan tersebut dapat dicapai melalui berbagai kegiatan diantaranya adalah pelatihan pembuatan pupuk organik cair eceng gondok dan keong mas. Pelatihan pembuatan pupuk juga bermanfaat bagi sektor pertanian untuk mengurangi biaya produksi sehingga pelatihan pembuatan pupuk organik cair signifikan untuk dilatihkan kepada Ibu-ibu PKK Dusun Semen Kecamatan Tuntang Kabupaten Semarang.

Kegiatan pelatihan pembuatan pupuk organik cair berbahan dasar eceng gondok dan keong mas dilakukan karena Ibu-ibu PKK di Dusun Semen sangat memerlukan keterampilan yang dapat dijadikan salah satu alternatif untuk mendirikan usaha. Selain itu, permasalahan hama yang sering dialami petani Dusun Semen adalah serangan hama salah satunya keong mas. Keong mas adalah hama penting pada tanaman padi yang belum dapat dikendalikan (Harahap et al., 2018). Keong mas akan memakan daun padi muda (Liunokas et al., 2019). Hal ini berakibat penurunan produksi padi dan bahkan gagal panen. Dalam $1 \mathrm{~m}^{2}$ tiga ekor keong mas dapat merusak lahan pertanian.

Eceng gondok digunakan sebagai bahan pembuatan pupuk organik cair karena jumlahnya yang melimpah di Rawa Pening. Peningkatan populasi eceng gondok terjadi saat musim kemariu hingga 70\% (Ilmiawan et al., 2018). Permasalahan lingkungan di Rawa Pening diantaranya penyumbatan saluran irigasi, pendangkalan penurunan hasil perikanan, dan kehilangan air akibat adanya proses evapotranspirasi (Ilmiawan et al., 2018). Danau Rawa Pening dijadikan pusat berbagai aktivitas perekonomian masyarakat sekitar. Aktivitas yang beragam mulai dari pariwisata, aktivitas nelayan, dan mandi cuci kakus (MCK) menyebabkan Rawa Pening mengalami eutrofikasi parah dimana hampir $70 \%$ wilayahnya 
tertutup eceng gondok, ganggang, serta beberapa paku air (Ilmiawan et al., 2018)(Ilmiawan et al., 2018). Tertutupnya perairan Rawa Pening me-ngancam kelestarian biota bawah air seperti ikan dan udang akibat kekurangan oksigen dan sinar matahari. Eceng gondok yang tumbuh secara melimpah mengaki-batkan mobilitas nelayan menjadi tergang-gu.

Pupuk organik cair yang berhasil dibuat oleh Ibu PKK dapat digunakan sebagai pupuk dalam mengelola lahan pertanian warga. Tanah yang diberi pupuk organic memiliki kualitas yang lebih baik dibandingkan tanah yang diberi pupuk anorganik. Kadar karbon organik pada tanah yang diberi pupuk organik terus menerus lebih baik dibandingkan tanah yang tidak diberi pupuk organik (Hartatik \& Sarmah, 2013).

Program pelatihan yang dilakukan oleh tim diharapkan dapat meningkatkan pengetahuan dan keterampilan Ibu-ibu PKK dusun Semen dalam memproduksi pupuk organik cair secara mandiri, serta hasil produksi pupuk organik cair skala rumah tangga dapat dimanfaatkan dan dijual untuk menambah penghasilan.

\section{Metode Pelaksanaan}

Kegiatan pengabdian dilaksanakan di dusun Semen, kecamatan Tuntang, kabupaten Semarang. Tim yang melaksanakan kegiatan pengabdian adalah mahasiswa Universitas Diponegoro Semarang. Kegiatan pengabdian dilaksanakan selama 4 bulan. Kegiatan yang dilakukan adalah kegiatan pelatihan dan pendampingan pada ibu-ibu PKK dusun Semen. Tahapan pelaksanaan kegiatan adalah sebagai berikut:

\section{Observasi Lapangan}

Kegiatan observasi lapangan merupakan tahapan awal dilakukannya kegiatan pengabdian. Obeservasi lapangan bertujuan untuk mengetahui kondisi mitra dan menentukan metode pelatihan yang sesuai dengan kondisi mitra. Observasi lapangan dilakukan dengan melihat kondisi sekitar dusun Semen dan melakukan wawancara kepada tokoh masyarakat yang ada di dusun Semen. Adapun tokoh masyarakat yang diwawancara adalah kepala dusun, lurah dan ketua PKK.

\section{Persiapan}

Tim melaksanakan kegiatan Persiapan dengan membuat video tutorial dan modul. Video tutorial ini diberikan pada ibu PKK dan diperlihatkan sebelum kegiatan berjalan agar Ibu PKK mengetahui tahapan pelatihan yang akan dilakukan. Modul yang diberikan bertujuan agar ibuibu PKK mendapatkan pengetahuan tambahan dan dapat mengikuti kegiatan pelatihan yang sudah disiapkan oleh tim dengan baik.

\section{Pelatihan}

Kegiatan pelatihan dilakukan dengan cara melakukan demonstrasi di depan ibuibu PKK kemudian ibu-ibu PKK dibagi dalam beberapa kelompok untuk melakukan kegiatan tersebut bersama-sama. Setiap kelopok akan didampingi oleh 1 orang anggota tim agar kegiatan berjalan dengan baik.

\section{Pendampingan}

Kegiatan pendampingan dilakukan setelah diadakan pelatihan. Kegiatan pendampingan ini dilakukan secara daring dan luring. Pendampingan bertujuan untuk mendampingi proses pembuatan pupuk yang dilakukan oleh ibu-ibu PKK secara mandiri.

\section{Evaluasi}

Tahap evaluasi akan menentukan keberhasilan program yang telah dilakukan. Kegiatan evaluasi dilakukan dengan melakukan wawancara terhadap ibu-ibu PKK dan melihat hasil pupuk organik cair yang telah dibuat secara mandiri.

\section{Hasil Dan Pembahasan}

Hasil yang diperoleh dari masingmasing kegiatan adalah sebagai berikut.

\section{Observasi Lapangan}


Observasi lapangan dilaksanakan dengan pemantauan kondisi sekitar secara langsung. berdasarkan hasil pengamatan ditemukan bahwa terdapat eceng gondok di Rawa Pening dengan jumlah yang melimpah. Jumlah eceng gondok yang melimpah menghambat kegiatan nelayan dalam mencari ikan karena eceng gondok menghambat perahu nelayan berjalan. Pengamatan yang dilakukan di area persawahan warga ditemukan jumlah keong mas yang cukup banyak. Keong mas menyebabkan terjadinya penurunan hasil panen karena keong mas akan memakan daun muda padi.

Observasi lapangan juga dilakukan dengan mewawancarai tokoh masyarakat yang ada di Dusun Semen. Tokoh masyarakat yang diwawancarai adalah Kepala Dusun, Lurah dan Ketua PKK. Berdasarkan hasil wawancara menunjukkan bahwa Ibu PKK Dusun Semen belum bisa mengolah eceng gondok dan keong mas menjadi suatu produk yang bermanfaat. Ibu PKK juga memiliki ketrampilan yang rendah sehingga dibutuhkan kegiatan pelatihan dan pendampingan untuk meningkatkan ketrampilan Ibu PKK Dusun Semen.

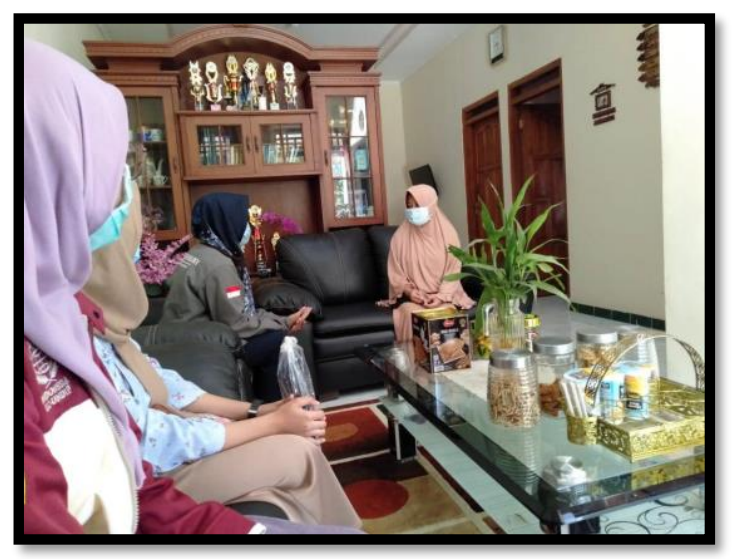

Gambar 1. Kegiatan wawancara dengan ketua PKK

\section{Persiapan}

Kegiatan persiapan dilakukan dengan pembuatan video tutorial dan pembuatan modul. video tutorial berisi tahapan pembuatan pupuk organik cair dari eceng gondok dan keong mas. Video tutorial ini bermanfaat agar Ibu PKK lebih paham dalam proses pembuatan pupuk organik cair.

Modul juga diberikan kepada Ibu PKK Dusun Semen agar dapat mengikuti kegiatan pelatihan dengan baik. Modul berisikan tahapan kegiatan yang akan dilakukan selama pelatihan. Modul yang diberikan berisi banyak ilustrasi agar memudahkan Ibu PKK dalam memahami kegiatan pelatihan dengan baik.

\section{Pelatihan}

Kegiatan pelatihan dilakukan dengan metode demonstrasi. Tim akan memberikan demonstrasi mengenai cara pembuatan pupuk organik cair dari eceng gondok dan keong mas. Kegiatan pelatihan dihadiri oleh 10 ibu PKK dengan tetap menjalankan protokol kesehatan yang berlaku. Keberjalanan kegiatan pelatihan dilakukan dengan membagi ibu PKK dalam beberapa kelompok yang nantinya setiap kelompok akan didampingi oleh tim agar dapat menjalankan kegiatan dengan baik.

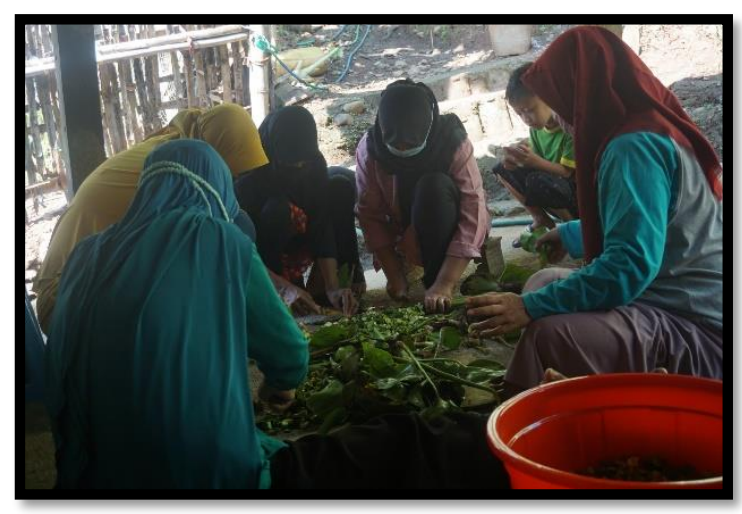

Gambar 2. Proses pembuatan pupuk organik cair

Perbandingan bahan yang digunakan dalam pembuatan pupuk organik cair yaitu $6 \mathrm{~kg}$ eceng gondok, $2 \mathrm{~kg}$ keong mas, $3,6 \mathrm{~kg}$ gula pasir, $2 \mathrm{~L}$ air cucian beras, $900 \mathrm{ml}$ EM4 dan 12 L air. Tahapan yang dilakukan dalam proses pembuatan pupuk organik cair dari eceng gondok dan keong 
mas adalah sebagai berikut: 1 . Keong mas dikeluarkan dari cangkangnya kemudian dihancurkan dengan chopper, 2. Eceng gondok dipisahkan antara batang daun dan akarnya kemudian dipotong, setelah dipotong dihancurkan dengan chopper, 3 . Eceng gondok dan keong mas yang sudah dichopper dimasukkan kedalam ember dan diberi gula pasir, air cucian beras, EM4 dan air, 4. Seluruh bahan diaduk dengan pengaduk dan ember ditutup, ditunggu hingga 28 hari agar fermentasi berjalan dengan optimal.

\section{Pendampingan}

Kegiatan pendampingan dilakukan dengan cara pemantauan secara langsung atau pemantauan menggunakan WhatssApp group. Pemantauan secara langsung dilakukan dengan melakukan wawancara secara langsung kepada ibu PKK dan memantau kegiatan yang dilakukan secara mandiri.

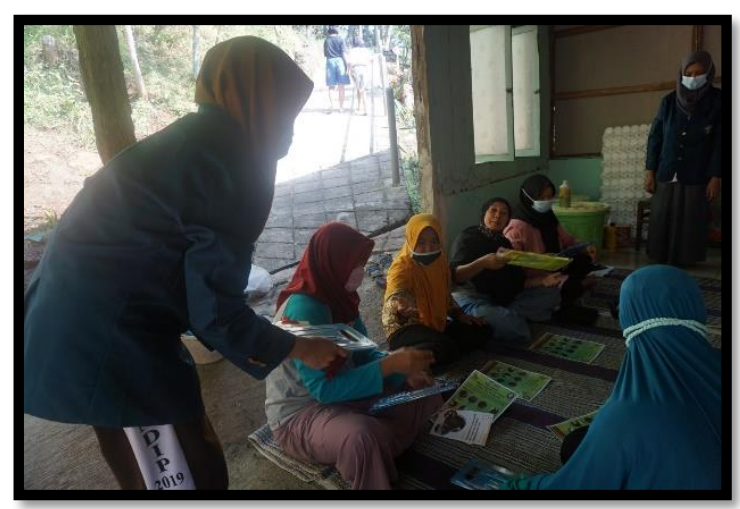

Gambar 3. Kegiatan diskusi pasca pelatihan pembuatan pupuk organik cair

Berdasarkan kegiatan pendampingan menunjukkan bahwa ibu-ibu PKK menunjukkan adanya perubahan pola perilaku kemandirian dalam penggunaan pupuk organik. Terjadi peningkatan ketrampilan dari Ibu PKK dalam pembuatan pupuk organik cair dari eceng gondok dan keong mas.

\section{Evaluasi}

Berdasarkan rangkaian kegiatan yang telah dilakukan, dari hasil angket menunjukkan bahwa kegiatan pember- dayaan berjalan dengan baik dan terjadi perubahan pola perilaku Ibu PKK selama mendapatkan kegiatan pelatihan dan setelah kegiatan pelatihan dapat dilihat pada Gambar 5. Angket yang sudah dikumpulkan dilakukan analisis secara deskriptif. Hasil angket menunjukkan bahwa dari $70 \%$ Ibu PKK yang belum pernah membuat pupuk organik kini $90 \%$ Ibu PKK telah memahami pembuatan pupuk organik cair. 90\% Ibu PKK juga mulai memahami pemanfaatan eceng gondok dan keong mas serta fungsi fermentasi dalam pembuatan Pupuk organik cair.

Sektor pertanian merupakan sektor yang penting bagi kelangsungan hidup bangsa. Beras menjadi bahan pangan utama bagi masyarakat Indonesia berasal dari sektor pertanian. Keberlangsungan dari sektor pertanian tidak lepas dari adanya penggunaan pupuk yang dapat membantu kesuburan. Pupuk merupakan bahan yang diberikan pada tanaman dengan kandungan unsur hara mikro maupun makro (Saepuloh et al., 2020). Pupuk membantu tanaman agar mendapatkan unsur hara yang baik sehingga menghasilka tanaman dengan kualitas yang baik. Pupuk diberikan kepada tumbuhan secara berkala seperti memberikan vitamin pada manusia. Pemberian pupuk pada dosis dan jangka waktu tertentu berfungsi agar unsur hara pada tanaman terpenuhi dengan baik sehingga menghasilkan tanaman dengan kualitas terbaik (Triadiawarman \& Rudi, 2019).

Pupuk yang digunakan dalam kegiatan pelatihan adalah pupuk organik cair. Pupuk organik cair merupakan hasil dari dekomposisi bahan organik yang telah diurai oleh mikroba sehingga menyediakan unsur hara yang dapat membantu tanaman untuk tumbuh dan berkembang (Siregar, 2018). Pupuk organik cair dipilih karena memiliki keunggulan diantaranya dapat memperbaiki sifat fisik, kimia dan biologi tanah (Aryani \& Musbik, 2018). Tanah yang sering diberi pupuk anorganik memiliki sifat yang keras sehingga organisme seperti cacing sulit untuk 
menggemburkan tanah. Hal ini dapat menyebabkan tanah tidak subur. Keunggulan lain dari penggunaan pupuk organik cair bagi tanaman adalah terjadinya peningkatan kualitas dari produk yang dihasilkan.

Eceng gondok digunakan sebagai bahan dasar pembuatan pupuk organik cair karena memiliki kandunan bahan organic sebesar $78,47 \%, \mathrm{C}$ organic $21,23, \mathrm{~N}$ total $0,28 \%$, $\mathrm{P}$ total $0,0011 \%$ dan $\mathrm{K}$ total 0,016\% (Moi, 2015). Berdasarkan kandungan yang dimiliki menunjukkan bahwa eceng gondok berpotensi untuk dijadikan bahan baku pupuk organik cair. Bahan organik yang dimiliki oleh eceng gondok dapat memenuhi kebutuhan organk bagi tanaman lainya. Ketersediaan eceng gondok di alam sangat melimpah karena eceng gondok dapat tumbuh dan berkembang dalam waktu yang cepat. Fenomena ini ditemukan pada Rawa Pening yang sebagian besar permukaannya ditutupi oleh eceng gondok. Permukaan Rawa Pening yang tertutup oleh eceng gondok mendapatkan perhatian serius dari pemerintah setempat. Hal ini dibuktikan dengan adanya kegiatan pembersihan eceng gondok secara berkala. Jumlah eceng gondok harus selalu dikurangi agar tidak menyebabkan eutrofikasi pada Rawa Pening.
Keong mas merupakan hama pertanian yang dijumpai di area persawahan yang memiliki kemampuan adaptasi dan reproduksi cukup tinggi. Hal ini menyebabkan keong mas jumlahnya sangat banyak dan mudah dijumpai di area persawahan (Abdullah et al., 2017). Prosentase penetasan dari telur keong mas adalah $85 \%$ artinya hampir seluruh telur yang dihasilkan oleh indukan keong mas dapat menetas menjadi keong mas. Penggunaan bahan kimia sering dilakukan untuk memberantas hama keong mas. Penggunaan bahan kimia terus menerus dan berlebih dapat menyebabkan terjadinya kerusakan alam dan terganggunya ekosistem di area persawahan.

\section{Pekerjaan responden}

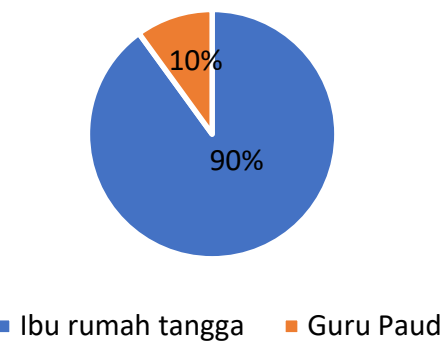

Gambar 4. Profil Peserta Kegiatan

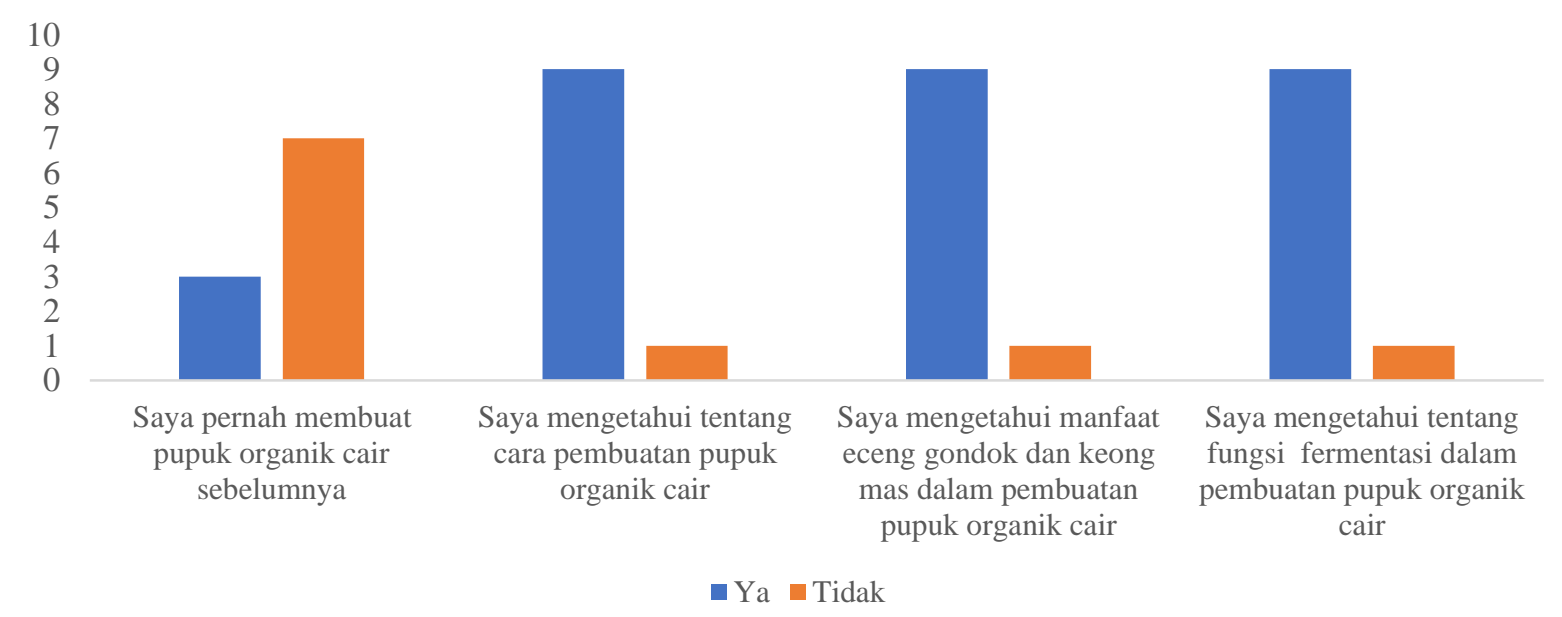

Gambar 5. Grafik pemahaman Ibu-Ibu PKK

Dusun Semen Tuntang Semarang pasca kegiatan 


\section{Simpulan}

\section{Penutup}

Berdasarkan kegiatan pengabdian yang telah dilaksanakan, dapat diambil beberapa kesimpulan diantaranya adalah 1) Seluruh rangkaian program terlaksana dengan baik dan sesuai dengan rencana, dan 2) Ibu-ibu PKK dusun Semen telah memiliki keterampilan tentang pembuatan pupuk organik cair eceng gondok dan keong mas yang dapat dijadikan usaha skala rumah tangga atau kelompok, 3) Program pengabdian yang dilakukan mulai dari koordinasi, pelatihan, hingga pendampingan mendapatkan partisipasi aktif dari ibu-ibu PKK desa.

\section{Saran}

Keberlanjutan program pasca pelatihan yang telah dilakukan memerlukan dukungan dari berbagai pihak. Kebutuhan peralatan yang mencukupi menjadi salah satu aspek penting agar nantinya dapat berkembang menjadi usaha mandiri oleh ibu PKK desa Tlompakan. Disarankan untuk pemerintah desa Tlompakan memberikan dukungan penuh kepada Ibu PKK berupa hibah peralatan untuk pembuatan pupuk organik cair. Saran juga diberikan kepada ibu-Ibu PKK desa tlompakan untuk membentuk susunan organisasi guna keberlanjutan usaha pupuk organik cair kedepannya serta memudahkan monitoring dan evaluasi oleh TIM PKM PM Universitas Diponegoro.

\section{Ucapan Terimakasih}

Diucapkan terima kasih kepada Dirjen Dikti yang telah memberikan pendanaan kepada tim sehingga pelaksanaan program pengabdian dapat berjalan dengan baik. Terima kasih juga disampaikan kepada Ibu-Ibu PKK dusun Semen yang telah menjalankan program dengan partisipatif, Ibu Ketua PKK dusun Semen serta kepala desa Tlompakan yang telah memberikan tim izin untuk melaksanakan program.
Abdullah, A., Nurjanah, N., \& Reyhan, M. (2017). Identification and Profiling of Active Compounds from Golden Apple Snail's Egg Pigments. Jurnal Pengolahan Hasil Perikanan Indonesia, 20(2), 286-295.

Aryani, I., \& Musbik, M. (2018). Pengaruh Takaran Pupuk Organik Cair Terhadap Pertumbuhan Tanaman Sawi Caisim (Brassica Juncea L) Di Polibag. Prospek Agroteknologi, 7(1), 60-68.

Harahap, P., Oemry, S., \& Lisnawati, L. (2018). Potensi Berbagai Tanaman Sebagai Moluskisida Nabati untuk Mengendalikan Keong Mas Pomacea canaliculata Lamarck (Mollusca: Ampullariidae) pada Tanaman Padi di Rumah Kaca. Talenta Conference Series: Agricultural and Natural Resources (ANR), 1(1), 87-94.

Hartatik, W., \& Sarmah. (2013). Pengaruh Pemberian Pupuk Organik Terhadap Kadar Asam Humat Dan Asam Fulvat Tanah. Jurnal Tanah Dan Iklim, 37(2), 79-86. https://doi.org/10.2017/jti.v37n2.2013 .79-86

Ilmiawan, D. F., Carnawi, C., Anwaristiawan, D., Varantika, N., Anisa, R. D., \& Kharis, M. (2018). Analisis dinamik model PredatorPrey pada penyebaran grass carp fish sebagai biokontrol populasi eceng gondok di Perairan Rawapening. Journal of Creativity Student, 1(1).

Liunokas, A. B., Bana, J. J., \& Amalo, D. (2019). Pengaruh Pemberian Ekstrak Pinang (Areca Catechu L.) Terhadap Kesintasan Telur Keong Mas (Pomacea Canaliculata Lamarck). Jurnal Biologi Tropis, 19(2), 294. https://doi.org/10.29303/jbt.v19i2.130 2

Moi, A. R. (2015). Pengujian pupuk organik cair dari eceng gondok (Eichhornia crassipes) terhadap pertumbuhan tanaman sawi (Brassica juncea). Jurnal MIPA, 4(1), 15-19.

Saepuloh, S., Isnaeni, S., \& Firmansyah,

\section{Daftar Pustaka}


E. (2020). Pengaruh Kombinasi Dosis Pupuk Kandang Ayam dan Pupuk Kandang Kambing Terhadap Pertumbuhan dan Hasil Pagoda (Brassicaee narinosa L.). AGROSCRIPT: Journal of Applied Agricultural Sciences, 2(1).

Siregar, M. (2018). Uji Pemangkasan Dan Pemberian Pupuk Kandang Terhadap Pertumbuhan Dan Produksi Padi Salebu. Jurnal Abdi Ilmu, 11(1), 4249.

Triadiawarman, D., \& Rudi, R. (2019). Pengaruh Dosis dan Interval Waktu Pemberian Pupuk Organik Cair Daun Gamal Terhadap Pertumbuhan dan Hasil Tanaman Sawi (Brassica Juncea L.). Jurnal Pertanian Terpadu, 7(2), 166-172.

Utomo, P., \& Prihatin, A. P. (2020). Jurnal Mitra Manajemen ( JMM Online ). Jurnal Mitra Manajemen, 4(4), 16511663.

Zurani, I. (2020). Dominasi Perempuan Pebisnis Dalam Rumah Tangga. WACANA: Jurnal Ilmiah Ilmu Komunikasi, 19(1), 72-81. 